\title{
The northernmost record of the Asian hornet Vespa velutina nigrithorax (Hymenoptera, Vespidae)
}

\author{
Martin Husemann ${ }^{1}$, Andreas Sterr ${ }^{2}$, Swen Maack ${ }^{3}$, Rudolf Abraham ${ }^{1}$ \\ 1 Centrum für Naturkunde, Martin-Luther-King Platz 3, 20146, Hamburg, Germany \\ 2 Osterbekstraße 107 a, 22083 Hamburg, Germany \\ 3 Bernstorffstrasse 155, 22767 Hamburg, Germany \\ http://zoobank.org/2E6EC504-3073-48E4-84E1-34F382BD8597 \\ Corresponding author: Martin Husemann (martin.husemann@uni-hamburg.de)
}

Academic editor: Danilo Harms • Received 16 October 2019 • Accepted 20 December 2019 • Published 4 February 2020

\begin{abstract}
For the first time the Asian hornet Vespa velutina has been found in Hamburg (Northern Germany). So far this is the northernmost occurrence of this originally SE-Asian species in Europe and in the world. It remains unclear whether this is a single accidentally translocated specimen or one of a population already reproducing. The find may suggest that the species will possibly spread much faster than previously anticipated and modelled.
\end{abstract}

\section{Key Words}

Hamburg, honeybees, invasion biology, neozoa, insect, pest organism, yellow legged hornet.

\section{Introduction}

Invasive species represent one of the big challenges in a globalized world as they more easily reach new habitats, may change local diversity patterns and often pose threats to native species and economy (Kenis et al. 2009, Simberloff et al. 2013, Bellard et al. 2016, Bradshaw et al. 2016). Despite rising attention to the problem, the number of invasives is constantly rising (Hulme 2009, Seebens et al. 2017). As such invasive species can be considered novel important ecological and evolutionary drivers (Didham et al. 2005).

One species originating in tropical South-East Asia (native range: north eastern India, southern, south western and central China, Hong Kong, Taiwan, Burma, Thailand, Laos, Vietnam, Peninsular Malaysia, Sumatra, Java, Lesser Sunda Islands, and Timor; Archer 1994, Villemant et al. 2011, see Rome et al. 2011 for a map), which has recently invaded parts of Europe and causes problems for apiculture, is the Asian hornet, Vespa velutina nigrithorax Lepeletier, 1836. The first European specimens were captured in southwestern France in 2005
(Haxaire et al. 2006, Rortais et al. 2010). After initiating a monitoring campaign in 2006 , the origin of the invasion was confirmed; a nest of the species was transported with pottery from eastern China (Villemant et al. 2006, Arca et al. 2015). Since then the species has quickly spread throughout much of France (Rortais et al. 2010, Monceau et al. 2014), but also parts of Spain (López et al. 2011), Portugal (Grosso-Silva and Maia 2012), Belgium (Bruneau 2011), Italy (Demichelis et al. 2012, Bertolino et al. 2016), the Netherlands (Smit et al. 2018, Slikboer and Zeegers 2019), Great Britain (Budge et al. 2017) and south western parts of Germany (Witt 2015, Verhaagh et al. 2018; newest and most northern record in Germany from Hessen in 2019, hessenschau.de) (see Rome and Villemant 2019 for an updated map). The species has been shown to be a fast invader spreading with an invasion speed of around $78 \mathrm{~km} /$ year in France (Robinet et al. 2017), but higher distances may be covered with means of anthropogenic accidental transportation (Robinet et al. 2018). In Hamburg a single specimen was collected alive in early September 2019 representing the northernmost find of the species so far. 


\section{Materials and methods}

A female worker of Vespa velutina nigrithorax (Fig. 1) was collected alive on the $3^{\text {rd }}$ of September 2019 in a hall of Neumann \& Müller GmbH \& Co. KG, Berzeliusstr. 19, 22113 Hamburg (Billbrook) (53.535855, 10.088256). The company is not involved in import or export and no goods were delivered at that time from areas where the species is known. The specimen was killed using ethyl acetate, mounted and photographed with a custom made DUN Inc. stacking system. The specimen was determined using the key by Archer (1994) and was added to the collection of the Zoological Museum Hamburg (ZMH-77474).

\section{Results and discussion}

So far Vespa velutina has only been found in the Southern areas of Germany (Rheinland-Pfalz, Baden-Württemberg, Hessen; Witt 2015, hessenschau.de, 21.10.19). The new record from Hamburg represents the northernmost point where the species has been found. Whether the species has already settled or whether the record represents a single introduction has to be determined in the future by monitoring the area, where the specimen was captured. However, considering the fast invasion speed of the species and its relatively high climatic tolerance it does not seem unlikely that the species reached Hamburg on natural routes and reproduces here (Ibáñez-Justicia and Loomans 2011). Yet, other models suggest that the Hamburg area is not suitable for the species today (Barbet-Massin et al. 2013, 2018; Villemant et al. 2011). As a harbor city with much import and export Hamburg remains a hub for invasive species, which was documented by the frequent occurrence of non-native taxa in the past (e.g. for plants - Schmidt 2014, or the Asian longhorned beetle Anoplophora glabripennis).

Nevertheless, if the current find represents a case of natural range expansion, the species invades new areas quicker than expected even in climatically less favorable regions. Yet, areas like the Netherlands have been modelled to be suitable climatically for the species (Ibáñez-Justicia and Loomans 2011) and a fast spread over Great Britain has been predicted (Keeling et al. 2017); hence, the occurrence in Hamburg may not be entirely surprising. Due to its potential harm on apiculture (Rome et al. 2011, Monceau et al. 2014, Requier et al. 2019), the species is considered an invasive species with strong impact (European Union 2016). Therefore, the current find needs to be taken seriously, no matter if it is only a single specimen or a member of an established population. The area should be monitored in the future to destroy any potential nests to slow the speed of invasion for the species (Rome and Villemant 2017, Lioy et al. 2019).

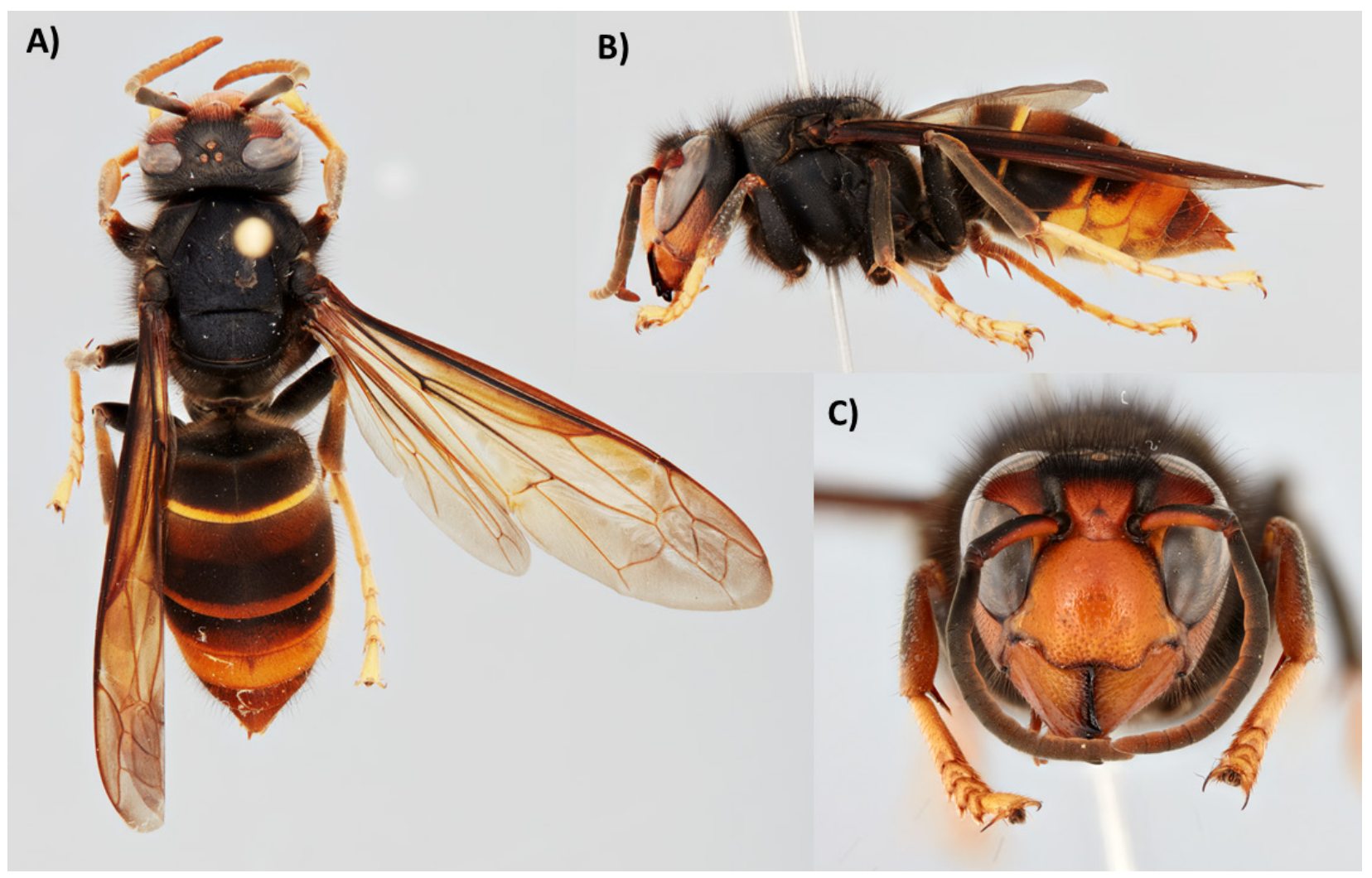

Figure 1. The specimen of Vespa velutina collected in Hamburg A dorsal view B lateral view C frontal view. 


\section{Acknowledgement}

We thank Thure Dalsgaard for preparing the specimen and taking photos. We further thank the Editor Danilo Harms, as well as Rebecca Kittel, Michael Ohl and Lars Krogmann and especially Quentin Rome for helpful comments on a previous version of the paper.

\section{References}

Arca M, Mougel F, Guillemaud T, Dupas S, Rome Q, Perrard A, et al. (2015) Reconstructing the invasion and the demographic history of the yellow-legged hornet, Vespa velutina, in Europe. Biological Invasions 17: 2357. http://doi.org/10.1007/s10530015-0880-9

Archer ME (1994) Taxonomy, distribution and nesting biology of the Vespa bicolor group (Hym., Vespinae). Entomological Monthly Magazine 130: 149-158.

Barbet-Massin M, Rome Q, Villemant C, Courchamp F (2018) Can species distribution models really predict the expansion of invasive species? PLOS ONE, 13(3): e0193085. http://doi.org/10.1371/journal. pone. 0193085

Barbet-Massin M, Rome Q, Muller F, Perrard A, Villemant C, Jiguet F (2013) Climate change increases the risk of invasion by the Yellow-legged hornet. Biological Conservation 157: 410. http://doi. org/10.1016/j.biocon.2012.09.015

Bellard C, Cassey P, Blackburn TM (2016) Alien species as a driver of recent extinctions. Biology Letters 12: 20150623. http://doi. org/10.1098/rsbl.2015.0623

Bertolino S, Lioy S, Laurino D, Manino A, Porporato M (2016) Spread of the invasive yellow-legged hornet Vespa velutina (Hymenoptera: Vespidae) in Italy. Applied Entomology and Zoology 51: 589-597. http://doi.org/10.1007/s13355-016-0435-2

Bradshaw CJA, Leroy B, Bellard C, Roiz D, Albert C, Fournier A, Barbet-Massin M, Salles J-M, Simard F, Courchamp F (2016) Massive yet grossly underestimated global costs of invasive insects. Nature Communications 7:12986. http://doi.org/10.1038/ ncomms 12986

Bruneau E (2011) Le frelon asiatique, déjà là? ActuApi 55: 1-6.

Budge GE, Hodgetts J, Jones EP, Ostojá-Starzewski JC, Jall J, Tomkies V, Semmence N, Brown M, Wakefield M, Stainton K (2017) The invasion, provenance and diversity of Vespa velutina Lepeltier (Hymenoptera: Vespidae) in Great Britain. PLoSOne 12: e0185172, 1-12. http://doi.org/10.1371/journal.pone.0185172

Demichelis S, Manimo A, Porpato M (2012) Trovato il primo nidi di Vespa velutina a Vallecrosia (IM). In: Communicato stampa. Università Degli Studi di Torino, Turin.

Didham KD, Tylianakis JM, Hutchinson MA, Ewers RM, Gemmell NJ (2005) Are invasive species the drivers of ecological change? Trends in Ecology and Evolution 20: 470-474. http://doi.org/10.1016/j. tree.2005.07.006

European Union (2016) Durchführungsverordnung (EU) 2016/1141 der Kommission vom 13. Juli 2016 zur Annahme einer Liste invasiver gebietsfremder Arten von unionsweiter Bedeutung gemäß der Verordnung (EU) Nr. 1143/2014 des Europäischen Parlaments und des Rates. Amtsblatt der Europäischen Union L 189/4.
Grosso-Silva JM, Maia M (2012) Vespa velutina Lepeltier, 1836 (Hymenoptera: Vespidae), new species for Portugal. Arquivos Entomolóxicos 6: 53-54.

Haxaire J, Bouguet J-P, Tamisier J-P (2006) Vespa velutina Lepeletier, 1836, une redoutable nouveauté pour la faune de France (Hym., Vespidae). Bulletin de la Société Entomologique de France 111: 194.

Hulme PE (2009) Trade, transport and trouble: managing invasive species pathways in an era of globalization. Journal of Applied Ecology, 46: 1018.

Ibáñez-Justicia A, Loomans AJM (2011) Mapping the potential occurrence of an invasive species by using CLIMEX: case of the Asian hornet (Vespa velutina nigrithorax) in The Netherlands. Proceedings of the Netherlands Entomological Society Meeting 22: 39-46.

Keeling MJ, Franklin DN, Datta S, Brown MA, Budge GE (2017) Predicting the spread of the Asian hornet (Vespa velutina) following its incursion into Great Britain. Scientific Reports 7: 6240, 1-7. http:// doi.org/10.1038/s41598-017-06212-0

Kenis M, Auger-Rozenberg M-AAR, Timms L, Péré C, Cock JW, Settele JSA, Lopez-Vaamonde C (2009) Ecological effects of invasive alien insects. Biological Invasions 11: 2145.

Lioy S, Manino A, Porporato D, Laurino D, Roman A, Capello M, Bertolino S (2019) Establishing surveillance areas for tackling Vespa velutina in outbreaks and over the border of its expanding range. NeoBiota 46: 51-69.

López S, Gonzáles M, Goldarazena A (2011) Vespa velutina Lepeltier, 1836 (Hymenoptera: Vespidae): first records in Iberian Peninsula. Bull OEPP/EPPO Bull 41: 439-441.

Monceau K, Bonnard O, Tiéry D (2014) Vespa velutina: a new invasive predator of honeybees in Europe. Journal of Pest Sciences 87: 1.16. http://doi.org/10.1007/s10340-013-0537-3

Requier F, Rome Q, Chiron G, Decante D, Marion S, Menard M, Muller F, Villemant C, Henry M (2019) Predation of the invasive Asian hornet affects foraging activity and survival probability of honey bees in Western Europe. Journal of Pest Science 92: 567578. http://doi org/10.1007/s10340-018-1063-0

Robinet C, Darrouzet E, Suppo C (2018) Spread modelling: a suitable tool to explore the role of human-mediated dispersal in the range expansion of the yellow-legged hornet in Europe. International Journal of Pest Management 65: 258-267. http://doi.org/10.1080/09670874 .2018 .1484529

Robinet C, Suppo C, Darrouzet E (2017) Rapid spread of the invasive yellow-legged hornet in France: the role of human-mediated dispersal and the effects of control measures. Journal of Applied Ecology 54: 205-215. http://doi.org/10.1111/1365-2664.12724

Rome Q, Villemant C (2017) Monitoring of the invasive hornet Vespa velutina (Hymenoptera, Vespidae). $13^{\text {th }}$ COLOSS Conference, Athens, Greece.

Rome Q, Perrard A, Muller F, Villemant C (2011) Monitoring and control modalities of a honeybee predator, the yellow-legged hornet Vespa velutina nigrithorax (Hymenoptera: Vespidae). Aliens: The Invasive Species Bulletin 31: 715.

Rome Q, Villemant C (2019) Le Frelon asiatique Vespa velutina. Inventaire National du Patrimoine Naturel - Muséum national d'Histoire naturelle [Ed], http://frelonasiatique.mnhn.fr/home/ [accessed on 30/10/2019]

Rortais A, Villemant C, Gergominy O, Rome Q, Haxaire J, Papachristoforou A, Arnold G (2010) A new enemy of honeybees in Europe: the 
Asian hornet, Vespa velutina. In: Settele J (Ed.) Atlas of biodiversity risks - from Europe to the globe, from stories to maps. Pensoft, Sofia, p. 11.

Schmidt KJ (2014) Plants in urban environments in relation to global change drivers at different scales. Dissertation at the University of Hamburg.

Seebens H, Blackburn TM, Dyer EE, Genovesi P, Hulme PE, Jeschke JM, et al. (2017) No saturation in the accumulation of alien species worldwide. Nature Communications 8: 14435. http://doi. org/10.1038/ncomms 14435

Simberloff D, Martin J-L, Genovesi P, Maris V, Wardle DA, Aronson J, et al. (2013) Impacts of biological invasions: what's what and the way forward? Trends in Ecology \& Evolution 28: 5866. http://doi. org/10.1016/j.tree.2012.07.013

Slikboer L, Zeegers T (2019) Der aziatische hoornaar in Nederland in 2019. EIS Report 2019.
Smit J, Noordijk J, Zeegers T (2018) De opmars van de Aziatische hoornaar (Vespa velutina) naar Nederland. Entomologische Berichten 78: 2-6.

Verhaagh M, Warzecha D, Grabow K (2018) Die Asiatische Hornisse Vespa velutina - ein neues Faunenelement in Baden-Württemberg. Mitteilungen des Entomologischen Vereins Stuttgart 53: 29-31.

Villemant C, Haxaire J, Streito J (2006) The discovery of the Asian hornet Vespa velutina in France. Insectes 143: 5.

Villemant C, Barbet-Massin M, Perrard A, Muller F, Gargominy O, Jiguet F, Rome Q (2011) Predicting the invasion risk by the alien bee-hawking yellow-legged hornet Vespa velutina nigrithorax across Europe and other continents with niche models. Biological Conservation 144: 21422150. http://doi.org/10.1016/j.biocon.2011.04.009

Witt R (2015) Erstfund eines Nestes der Asiatischen Hornisse Vespa velutina Lepeletier, 1838 in Deutschland und Details zum Nestbau (Hymenoptera, Vespinae). Ampulex 7: 42-53. 